\title{
PENERAPAN TEORI APOS (ACTION, PROCESS, OBJECT, SCHEMA) UNTUK MENINGKATKAN PEMAHAMAN KONSEP PROGRAM LINIER BAGI MAHASISWA PROGRAM STUDI PENDIDIKAN MATEMATIKA TAHUN AKADEMIK 2015/2016
}

\author{
${ }^{1}$ Yunita Septriana Anwar, ${ }^{2}$ Abdillah \\ ${ }^{1,2}$ Dosen Program Studi Pendidikan Matematika, Universitas Muhammadiyah Mataram \\ Email : na2_math@yahoo.com
}

\begin{abstract}
ABSTRAK
Penelitian ini bertujuan untuk untuk meningkatkan pemahaman konsep Program Linier bagi mahasiswa program studi pendidikan matematika tahun akademik 2015/2016 FKIP UM Mataram. Penelitian ini merupakan penelitian tindakan kelas yang dilaksanakan dalam dua siklus dan disesuaikan dengan cakupan materi Metode Simpleks dan Primal-Dual pada matakuliah Program Linier melalui penerapan Teori APOS (Action, Process, Object, Schema). Setiap siklus meliputi tahapan-tahapan kegiatan, yaitu perencanaan, pelaksanaan tindakan, observasi, evaluasi, dan refleksi. Subjek penelitian adalah mahasiswa semester satu berjumlah 19 mahasiswa. Penerapan Teori APOS sudah dapat meningkatkan kemampuan mahasiswa dalam memecahkan masalah dalam Program Linier dimana pada siklus I rata-rata skor aktivitas sebesar 9,0 dengan kategori kurang aktif dan meningkat pada siklus II sebesar 13,0 dengan kategori aktif. Sedangkan hasil belajar pada siklus I diperoleh rata-rata kelas sebesar 66,11 dimana sebanyak 57,89\% mahasiswa memperoleh nilai dibawah 75. Pada siklus II terjadi peningkatan hasil belajar dengan rata-rata kelas sebesar 75,83 dimana sebanyak 52,63\% mahasiswa memperoleh nilai dibawah 75 dimana nilai ini sudah mencapai indikator keberhasilan yang ditetapkan.
\end{abstract}

Kata kunci : Teori APOS, Program Linier, Metode Simpleks, Primal-Dual

\section{PENDAHULUAN}

Pemprograman linier adalah metode matematik dalam mengalokasikan sumber daya yang terbatas untuk mencapai suatu tujuan seperti memaksimalkan keuntungan atau meminimumkan biaya. Program linier berkaitan dengan penjelasan suatu kasus dalam dunia nyata sebagai suatu model matematik yang terdiri dari sebuah fungsi tujuan linier dengan beberapa kendala linier (Taha, 1993). Sebagai salah satu matakuliah wajib dalam kurikulum program studi pendidikan matematika diseluruh perguruan tinggi di Indonesia, Program Linier memegang perananan penting dalam masalah ekonomi, industri, sosial dan berbagai macam disiplin ilmu lain. Program Linier juga lanjutan dari beberapa matakuliah seperti Aljabar Linier, Metode Numerik, dan juga menjadi prasyarat beberapa matakuliah dalam kurikulum program studi matematika.

Pembelajaran Program Linier yang dilaksanakan di program studi pendidikan Matematika FKIP UMM masih belum memberikan hasil yang memuaskan. Hal ini dapat dikarenakan oleh beberapa faktor yang meliputi mahasiswa, dosen, dan juga dari karakteristik dari Program Linier itu sendiri. Dari faktor mahasiswa, input mahasiswa yang diterima program studi matematika didominasi oleh mahasiswa dengan latarbelakang bukan dari jurusan program IPA ketika di bangku sekolah menengat atas sehingga dasar konsep matematika mahasiswa masih rendah dan juga ada beberapa topik matematika yang tidak mereka dapatkan seperti di program IPA. Sedangkan dari faktor dosen dalam hal pemilihan metode dalam pembelajaran di kelas dimana dosen hanya menjelaskan rumus-rumus dalam buku teks, memberikan contoh-contoh yang berkaitan dengan rumus-rumus yang diajarkan, memberikan latihan, dan di akhir pembelajaran dosen memberikan tugas yang mengakibatkan mahasiswa cenderung bersikap pasif selama proses pembelajaran. Konsep-konsep dalam Program Linier memerlukan perhitungan yang rumit bahkan terkadang harus digambarkan dalam grafik dengan banyak fungsi kendala yang tidak mudah untuk dikerjakan. Selain itu keterbatasan buku-buku teks Program Linier yang berbahasa Indonesia juga masih sangat sedikit sehingga pembelajan Program Linier masih belum mampu memfaslitasi pemahaman konsep Program Linier secara utuh.

Teori APOS (Action, Process, Object, Schema) adalah yang diperkenalkan oleh Dubinsky yang menguraikan tentang bagaimana kegiatan mental seorang anak yang berbentuk aksi, proses, obyek, dan skema ketika mengkonstruksi konsep matematika. orang anak dapat mengkonstruksi konsep matematika dengan baik apabila anak tersebut mengalami aksi (action), proses (processes), obyek (objects), dan skema (schema). Seorang anak dikatakan telah memiliki suatu 
aksi, jika anak tersebut memusatkan pikirannya dalam upaya memahami konsep matematika yang dihadapinya. Seorang anak dikatakan telah memiliki suatu proses, jika berpikirnya terbatas pada konsep matematika yang dihadapinya dan ditandai dengan munculnya kemampuan untuk membahas konsep matematika tersebut. Seorang anak dikatakan telah memiliki obyek, jika anak tersebut telah mampu menjelaskan sifat-sifat dari konsep matematika. Seorang anak dikatakan telah memiliki skema, jika anak tersebut telah mampu mengkonstruksi contoh-contoh konsep matematematika sesuai dengan persyaratan yang telah ditentukan. Teori APOS dikhususkan untuk pembelajaran matematika di tingkat perguruan tinggi, yang mengintegrasikan penggunaan komputer, belajar dalam kelompok kecil, dan memperhatikan konstruksikonstruksi mental yang dilakukan oleh mahasiswa dalam memahami suatu konsep matematika (Arnawa, 2009).

Pendekatan APOS dapat diterapkan dalam pemebelajaran Program Linier untuk meningkatkan pemahaman mahasiswa karena pendekatan APOS dapat digunakan untuk mengetahui kesulitan mahasiswa dalam memahami materi Program Linier dan mengetahui konstruksi mental siswa dalam membangun pengetahuan tentang konsep Program Linier melalui tindakan, proses, objek, dan skema.

Sudah banyak dilakukan penelitian tentang penggunaan teori APOS pada pembelajaran tingkat tinggi, terutama yang berkaitan dengan peningkatan hasil belajar secara umum. Permasalahan yang akan dikaji dan ditelaah dalam penelitian ini adalah "Bagaimana penerapan Teori Apos (Action, Process, Object, Schema) dapat meningkatkan pemahaman konsep Program Linier bagi mahasiswa program studi pendidikan matematika tahun akademik 2016/2017?"

\section{TINJAUAN PUSTAKA}

\section{A. TINJAUAN MATAKULIAH PROGRAM LINIER}

Program Linier merupakan metode matematik dalam mengalokasikan sumber daya yang terbatas untuk mencapai suatu tujuan seperti memaksimumkan keuntungan dan meminimumkan biaya. Program Linear juga dapat diartikan sebagai suatu program untuk menyelesaikan permasalahn yang batasbatasannya berbentuk pertidaksamaan linear yang terdiri dari dua bagian, yaitu fungsi kendala dan fungsi objektif. Fungsi kendala adalah batasanbatasan yang dipenuhi, sedangkan fungsi objektif adalah fungsi yang nilainya akan dioptimumkan (dimaksimumkan adan diminimumkan). Dalam program linear ini, batasan- batasan atau kendalakendala yang terdapat didalam masalah Program Linear diterjemahkan terlebih dahulu kedalam bentuk perumusan matematika, yang disebut model matematika.

Model matematis Program Linear dalam bentuk standar dirumuskan sebagai
Maksimal atau Minimal : $Z=\sum_{j=1}^{n} C_{j} x_{j}$ untuk $j=1,2, \ldots, n$

dengan kendala :

$$
\begin{aligned}
& \sum_{j=1}^{n} a_{i j} x_{j}\left[\begin{array}{l}
\leq \\
= \\
\geq
\end{array}\right] b_{i} \\
& x_{j} \geq 0
\end{aligned}
$$

Keterangan:

$Z \quad=$ Fungsi Tujuan

$x_{j}=$ Variabel keputusan atau kegiatan ke- $j$

$C_{j}=$ Nilai kontribusi dari variabel keputusan $j$

$a_{i j}=$ Koefisien teknologi dalam kendala ke-m pada aktivitas ke- $i$

$b_{i}$ = Sumberdaya yang terbatas / konstanta dari kendala ke- $i$.

Ada dua metode penyelesaian masalah yang digunakan dalam Program Linier, yaitu metode grafis dan metode simpleks. Umumnya metode grafis terbatas untuk masalah yang melibatkan dua variabel dan cukup sulit digunakan untuk masalah multivariabel. Metode simpleks lebih mudah digunakan untuk masalah Program Linier yang melibatkan banyak variabel. Penentuan solusi optimal pada metode simpleks didasarkan pada teknik eliminasi Gauss-Jordan yang dilakukan tahap demi tahap yang disebut dengan iterasi.

Konsep-konsep dalam Program Linier yang banyak melibatkan operasi aljabar, penggambaran grafik, dan metode numerik yang merupakan konsep-konsep matematika tingkat tinggi yang tidak mudah dipahami oleh mahasiswa. Sehingga menyelesaikan suatu Program Linier bukanlah hal yang mudah. Penyediaan software komputer dapat membantu mahasiswa dalam memahami konsep-konsep Program Linier dan mencari solusi suatu Program Linier. Software LINDO merupakan salah satu software yang dapat digunakan untuk menyelesaikan masalah-masalah dalam Program Linier dari yang sederhana hingga kompleks. LINDO adalah sebuah paket program under Windows yang bisa digunakan untuk mengolah kasus pemrograman linier, dilengkapi dengan berbagai perintah yang memungkinkan pemakai menikmati kemudahan-kemudahan di dalam memperoleh informasi maupun mengolah data atau memanipulasi data.

\section{B. TEORI APOS}

Teori APOS merupakan singkatan dari aksi (actions), proses (processes), obyek (objects), dan skema (schema). Dalam pendekatan APOS, pemahaman tentang konsep matematika merupakan hasil konstruksi atau rekonstruksi dari objek-objek matematika yang dilakukan melalui aksi-aksi matematika, proses-proses, dan objekobjek yang diorganisasikan dalam suatu skema untuk menyelesaikan suatu permasalahan. 
Karakteristik pembelajaran matematika dengan pendekatan APOS yaitu menganalisa pengkonstruksian mental dalam memahami suatu konsep matematika, penggunaan lembar kerja siswa dalam pembelajaran, siswa belajar dalam kelompok kecil, dan pembelajaran menggunakan siklus ACE terdiri dari tiga fase yaitu aktivitas (Activities), diskusi kelas (Class discussion), dan latihan soal (Exercises).

Berikut ini diberikan deskripsi yang lebih lengkap untuk masing-masing konstruksi mental yang dimaksud.

1. Aksi (Action)

Aksi adalah suatu transformasi yang diterima oleh individu sebagai hal yang eksternal. Transformasi dilakukan dengan bereaksi terhadap petunjuk-petunjuk eksternal yang memberikan rincian yang tepat mengenai langkah-langkah apa yang harus diambil. Sebagai contoh, mahasiswa yang tidak dapat menafsirkan situasi sebagai fungsi kecuali jika ia mempunyai formula untuk menghitung nilai fungsinya, maka individu tersebut terbatas hanya pada action konsep fungsi.

2. Proses (Process)

Individu yang sudah mengkonstruksi process konsep dapat menguraikan atau bahkan membalikkan langkah-langkah dari transformasi tanpa benar-benar melakukannya. Berbeda dengan action, process dirasakan oleh individu sebagai hal yang internal dan dibawah kontrol individu tersebut. Dalam kasus fungsi, process konsep memungkinkan individu untuk memaknai fungsi sebagai menerima satu atau lebih variabel bebas sebagai input, melakukan satu atau lebih operasi pada input, dan mengembalikan hasil itu sebagai output.

3. Objek (Object)

Ketika individu berefleksi pada operasi yang diterapkan pada process tertentu, menjadi sadar terhadap process sebagai keseluruhan, menyadari bahwa transformasi (baik action maupun process) dapat bertindak padanya, dan benar-benar dapat mengkonstruksi transformasi itu, maka individu tersebut memaknai process sebagai object. Dalam kasus fungsi, process fungsi telah di-encapsulasi menjadi object, ketika individu dapat memikirkan tentang memanipulasi fungsi seperti penjumlahan, perkalian, atau hanya membentuk himpunan fungsi.

4. Skema (Schema)

Sekali dikonstruksi, object dan process dapat diinterkoneksi dengan berbagai cara. Process dan object dihubungkan dengan fakta bahwa process bertindak pada object.
Kumpulan dari action, process, dan object lainnya yang terhubung secara padu dan diorganisasi secara terstruktur dalam pikiran individu disebut schema. Schema ini yang dapat diandalkan dalam menghadapi persoalan dalam bidang matematika. Perbedaan antara schema dengan konstruksikonstruksi mental lainnya adalah seperti perbedaan dalam bidang biologi antara organ dengan sel. Keduanya adalah object, tetapi organ (schema) memberikan keperluankeperluan agar sel berfungsi sebagaimana mestinya. Schema dari seorang individu adalah keseluruhan pengetahuan yang ia hubungkan secara sadar maupun tidak sadar dengan konsep matematika tertentu. Seorang individu dapat mempunyai schema untuk fungsi, schema untuk turunan, dan lain-lain. Schema sendiri dapat diperlakukan sebagai object dan termuat dalam organisasi schema pada tingkatan yang lebih tinggi. Sebagai contoh, fungsi-fungsi dapat dinyatakan sebagai himpunan, operasi pada himpunan tersebut didefinisikan, dan sifat-sifat dari operasinya dapat diperiksa. Semua ini dapat diorganisasi untuk membentuk schema untuk ruang fungsi yang kemudian dapat diterapkan kepada konsep-konsep seperti ruang dual, ruang pemetaan linear, dan aljabar fungsi.

Teori APOS sangat baik digunakan untuk memahami pembelajaran mahasiswa dalam berbagai topik matematika di perguruan tinggi, seperti kalkulus, aljabar abstrak, statistik, matematika diskrit, Program Linier, dan sebagainya. Ada beberapa hal yang dapat dipandang sebagai karakteristik pembelajaran berdasarkan teori APOS, yaitu pembelajarannya meliputi/mengikutsertakan: (1) pengetahuan dikonstruksi mahasiswa melalui konstruksi mental APOS, (2) menggunakan komputer, (3) mahasiswa belajar dalam kelompok kecil, (4) menggunakan siklus ACE (activity, class discussion, excercise) (Arnawa, 2007).

Secara garis besarnya, perbedaan karakteristik pembelajaran berdasarkan teori APOS dengan pembelajaran konvensional dapat digambarkan sebagai berikut. Pertama, pada pembelajaran berdasarkan teori APOS: (1) bahan ajar disusun dengan memperhatikan tahapantahapan konstruksi mental aksi, proses, objek, dan skema, dan (2) mahasiswa terlibat secara aktif dalam pembelajaran, ide-ide matematika ditemukan mahasiswa melalui fakta-fakta yang diperoleh dalam kegiatan laboratorium. Sedangkan pada pembelajaran secara konvensional: (1) bahan ajar tidak dirancang secara khusus, biasanya mengacu kepada buku rujukan atau diktat yang dibuat dosen, dan (2) 
mahasiswa menerima informasi secara pasif, ideide matematika diberikan dalam bentuk jadi. Kedua, pada pembelajaran berdasarkan teori APOS: dosen berperan sebagai fasilitator, yaitu memberikan bantuan kepada mahasiswa, kelompok mahasiswa, atau keseluruhan anggota kelas melalui teknik scaffolding, misalnya dengan mengajukan pertanyaan dan memberikan hints dengan berbagai cara. Sedangkan pada pembelajaran secara konvesional: dosen berperan sebagai penyampai pengetahuan. Ketiga, pada pembelajaran berdasarkan teori APOS: ada interaksi antara mahasiswa dengan mahasiswa dan mahasiswa dengan dosen, mahasiswa belajar dari teman melalui kerja kelompok, diskuai, dan saling mengoreksi (interaksi multi arah). Sedangkan pada pembelajaran secara konvensional: interaksinya bersifat satu arah atau dua arah (Arnawa, 2009).

\section{METODE PENELITIAN}

A. Jenis Penelitian

Jenis penelitian ini adalah penelitian tindakan kelas (classroom action research). Penelitian tindakan kelas merupakan proses investigasi terkendali yang berdaur ulang dan bersifat reflektif mandiri yang dilakukan oleh dosen atau guru yang memiliki tujuan untuk melakukan perbaikan terhadap sistem, cara kerja, proses, isi, kompetensi, atau situasi pembelajaran (Susilo, 2009). Faktor-faktor yang diselidiki dalam penelitian ini meliputi faktor mahasiswa yaitu aktivitas dan pemahaman konsep mahasiswa dalam memecahkan masalah Program Linier melalui penerapan Teori APOS (action, process, object, schema) dan faktor aktivitas mahasiswa dalam pembelajaran melalui penerapan Teori APOS dalam pembelajaran.

Penelitian ini direncanakan dilaksanakan dalam dua siklus disesuaikan dengan cakupan materi Metode Simpleks dan Masalah Primal-Dual pada matakuliah Program Linier. Setiap siklus meliputi tahapan-tahapan kegiatan, yaitu perencanaan, pelaksanaan tindakan, observasi, evaluasi, dan refleksi.

\section{Perencanaan}

Pada tahap perencanaan, peneliti melakukan kegiatan yang diperlukan untuk mendukung kelancaraan pelaksanaan pra penelitian dan penelitian, yaitu: menyusun RPP yang berbasis Teori APOS, menyusun lembar kerja mahasiswa (LKM) yang mendukung RPP, menyusun lembar observasi aktivitas mahasiswa, dan menyusun soal evaluasi untuk tiap siklus penelitian.

\section{Pelaksanaan Tindakan}

Pada tahap pelaksanaan tindakan, peneliti melaksanakan pembelajaran berbasis Teori APOS. Kegiatan pembelajaran dilakukan dalam dua siklus, dengan masing-masing siklus terdiri atas tiga pertemuan. Pada siklus I, materi yang dibahas adalah Metode Simpleks pada pertemuan pertama dan kedua, kemudian evaluasi siklus I. Pada siklus II, materi yang dibahas adalah Masalah Primal-Dual dengan tindakan perbaikan yang dilakukan setelah refleksi dari siklus I.

\section{Tahap Observasi dan Evaluasi}

Kegiatan observasi dilakukan selama berlangsungnya pembelajaran dikelas untuk mengetahui aktivitas mahasiswa selama proses pembelajaran dengan Teori APOS.

\section{Tahap Refleksi}

Pada tahap ini yang dilakukan adalah merefleksi tindakan yang telah dilakukan dengan melihat hasil observasi dan evaluasi untuk mengidentifikasi kekurangan yang ada dan menganalisisnya kemudian dilakukan langkahlangkah perbaikan pada siklus selanjutnya.

\section{B. Tempat dan Subjek Penelitian}

Penelitian ini dilaksanakan di FKIP UM Mataram dengan subjek penelitian adalah mahasiswa semester IV tahun akademik 2016/2017.

\section{Instrumen}

Instrumen penelitian ini berupa lembar observasi aktivitas mahasiswa selama proses pembelajaran dengan Teori APOS dan tes hasil belajar dimana setiap item tes yang telah dibuat diharapkan dapat merefleksikan pemahaman konsep-konsep dalam Program Linier.

\section{Analisis Data}

\section{Data Hasil Belajar Program Linier}

\section{a. Ketuntasan individu}

Kriteria siswa dikatakan tuntas secara individu adalah jika mahasiswa tersebut memperoleh nilai lebih dari atau sama dengan 75 , dimana nilai 75 diperoleh berdasarkan pertimbangan dosen mengenai kemampuan awal mahasiswa dan juga literatur yang tersedia.

b. Menentukan nilai rata-rata hasil evaluasi

Untuk mengetahui hasil belajar mahasiswa, hasil evaluasi akan dianalisis secara deskriptif, yaitu menentukan rata-rata nilai hasil evaluasi. Analisis untuk mengetahui rata-rata nilai hasil evaluasi dirumuskan sebagai berikut:

Keterangan:

$$
M=\frac{\sum_{i=1}^{n} x_{i}}{n}
$$

$M$ = Rata-rata nilai hasil evaluasi mahasiswa

$\mathrm{x}_{\mathrm{i}}=$ Nilai masing-masing mahasiswa

$n$ = Jumlah siswa yang mengikuti tes 
E. Indikator Keberhasilan

Indikator keberhasilan dari penelitian ini adalah pemahaman mahasiswa dalam memecahkan masalah Program Linier meningkat hingga rata-rata skor kemampuan pemahaman pemecahan masalah mahasiswa lebih besar atau sama dengan 75. Nilai ini diambil berdasarkan hasil observasi pra tindakan yang dilakukan dosen pada matakuliah sebelumnya dan juga mempertimbangkan referensi dan fasilitas pembelajaran yang tersedia.

\section{HASIL PENELITIAN DAN PEMBAHASAN \\ A. Hasil Penelitian \\ 1. Pra Tindakan}

Hasil observasi pra tindakan adalah proses pembelajaran dikelas yang terlihat masih terfokus pada dosen dan kurangnya aktivitas mahasiswa. Indikasinya bahwa dosen belum memvariasikan metode yang dilaksanakan dikelas dimana masih menggunakan metode ceramah yang kurang mengaktifkan mahasiswa, kurang menggunakan media dan reverensi pembelajaran. Berdasarkan hasil observasi pra tindakan, dapat diidentifikasi beberapa permasalahan dalam proses perkulihan serta perilaku yang ditunjukkan mahasiswa selama perkuliahan. Maka, untuk mengatasi permasalahan tersebut peneliti bermaksud menerapkan teori APOS dalam perkuliahan Program Linier sebagai upaya peningkatan pemahaman mahasiswa pada konsep Program Linier. Pemilihan teori ini didasarkan pada latarbelakang masalah yang dihadapai pada proses pembelajaran Program Linier yang masih belum memberikan hasil yang memuaskan.

\section{Pelaksanaan Tindakan Siklus I}

\section{a. Perencanaan}

Perencanaan pada siklus I meliputi penyusunan rencana pelaksanaan pembelajaran, menyusun instrumen pembelajaran berbasis Teori APOS, menyiapkan tes untuk mengetahui tingkat kemampuan mahasiswa dalam pemecahan masalah, dan menyiapkan pedoman penilaian tes.

\section{b. Pelaksanaan}

Pelaksanaan tindakan pada siklus I pertemuan pertama membahas pendahuluan dan langkah-langkah penyelesaian masalah Program Linier dengan metode simpleks. Dosen membuka pelajaran dengan salam dan menyampaikan tujuan pembelajaran yang ingin dicapai. Dosen memotivasi mahasiswa dengan menyampaikan latarbelakang munculnya metode simpleks sebagai solusi lain untuk masalah Program Linier yang lebih operasional dibandingkan dengan metode grafis. Selanjutnya dosen memberikan apersepsi dengan mengingatkan kembali mengenai metode Gauss-Jordan dalam menyelesaiakan sistem persamaan linier.
Setelah apersepsi, dosen menyampaikan langkah-langkah dalam menyelesaikan masalah Program Linier dengan metode simpleks melalui slide presentasi yang telah disiapkan. Dosen juga menjelaskan cara menyelesaikan masalah Program Linier dengan metode simpleks dengan memanfaatkan software LINDO 6.1. Software ini sangat mudah digunakan dan memberikan hasil keluaran yang detail untuk setiap iterasi dalam metode simpleks. Selanjutnya, dosen membagi mahasiswa kedalam kelompok-kelompok kecil yang terdiri dari dua sampai tiga mahasiswa. Setiap kelompok diberikan satu soal permasalahan program linier yang akan diselesaikan dengan metode simpleks dan juga diberikan link untuk mengunduh software LINDO 6.1. Pada tahap ini mahasiswa melakukan aksi (actions), proses (prosesses), dan objek (objects), serta skema (schema) terhadap petunjuk-petunjuk yang diberikan dosen mengenai langkah-langkah dalam menyelesaikan masalah Program Linier.

Selanjutnya tiap kelompok mencoba menyelesaikan masalah Program Linier yang diberikaan dengan menggunakan software LINDO 6.1 dan mencocokan jawaban hasil dari LINDO 6.1 dengan jawaban yang telah dikerjakan sebelumnya. Tiap-tiap kelompok mempresentasikan hasil diskusi menegenai jawaban dari masing-masing masalah Program Linier yang diberikan dan kelompok yang lain memberi tanggapan berupa masukan maupun pertanyaan jika terdapat bagian pembuktian yang tidak dipahami. Dosen memberikan penguatan dan penegasan jawaban diakhir diskusi dan bersama menarik kesimpulan apa yang telah dipelajari.

c. Hasil Observasi

Tabel 1. Hasil observasi aktivitas belajar mahasiswa siklus I

\begin{tabular}{llcc}
\hline \multirow{2}{*}{ No. Indikator } & \multicolumn{2}{c}{ Rata-Rata skor } \\
& \multicolumn{1}{c}{ Pert. 1 } & Pert.2 \\
\hline 1. & $\begin{array}{l}\text { Kegiatan visual (visual } \\
\text { activities) }\end{array}$ & 2,0 & 2,0 \\
2. & $\begin{array}{l}\text { Kegiatan lisan (oral } \\
\text { activities) }\end{array}$ & 1,0 & 1,0 \\
3. $\quad \begin{array}{l}\text { Kegiatan mendengarkan } \\
\text { (listening activities) }\end{array}$ & 2,0 & 2,0 \\
4. $\quad \begin{array}{l}\text { Kegiatan menulis (writing } \\
\text { activities) }\end{array}$ & 1,0 & 2,0 \\
5. $\quad \begin{array}{l}\text { Kegiatan motorik (motor } \\
\text { activities) }\end{array}$ & 1,0 & 2,0 \\
6. $\quad \begin{array}{l}\text { Kegiatan mental (mental } \\
\text { activities) }\end{array}$ & 1,0 & 1,0 \\
\hline Jumlah skor pertemuan & 8,0 & 10,0 \\
Rata-rata skor & \multicolumn{2}{c}{9,0} \\
Kategori aktivitas & \multicolumn{3}{c}{ Kung Aktif } \\
\hline
\end{tabular}




\section{d. Evaluasi}

Evaluasi dilakukan pada 2 Juni 2016 dengan jumlah mahasiswa yang mengikuti tes adalah 19 orang dengan nilai tertinggi adalah 100 sedangkan nilai terendah adalah 30,0. Rata-rata kelas diperoleh sebesar 66,11 dimana sebanyak $57,89 \%$ mahasiswa memperoleh nilai diatas 75 .

\section{e. Refleksi}

Proses pembelajaran mata kuliah Program Linier pada siklus I difokuskan agar mahasiswa dapat memahami penyelesaian masalah Program Linier dengan metode Simpleks. Dari hasil pengamatan, dosen sudah menerapkan pembelajaran sesuai dengan langkah-langkah pendekatan teori APOS. Dari hasil tindakan yang sudah dilaksanakan, masih perlu adanya perbaikan-perbaikan sebagai berikut:

1. Dalam hasil evaluasi siklus I, banyak mahasiswa yang masih keliru dalam pembentukan tabel-tabel iterasi dalam setiap langkah penyelesaian dengan metode Simpleks yang meliputi pemilihan kolom kunci, elemen pivot, nilai kanan, dan penentuan batas akhir dalam proses iterasi sehingga dosen perlu mengingatkan kembali mengenai langkah-langkah penyelesaian masalah Program Linier dengan metode Simpleks.

2. Untuk LKM (Lembar Kerja Mahasiswa) yang berisi soal-soal yang cukup kompleks, dosen sebaiknya menambahkan catatan-catatan kecil untuk membantu penyelesaian yang memanfaatkan prinsip-prinsip prasyarat dalam matakuliah Program Linier.

\section{Pelaksanaan Tindakan Siklus II}

\section{a. Perencanaan}

Perencanaan tindakan siklus II merupakan rancangan yang telah disusun berdasarkan hasil refleksi siklus I. Langkah-langkah perencanaan siklus II meliputi penyusunan rencana pelaksanaan pembelajaran, menyusun instrumen pembelajaran berbasis Teori APOS, menyiapkan tes untuk mengetahui tingkat kemampuan mahasiswa dalam pemecahan masalah, menyiapkan pedoman penilaian tes, dan menyiapkan lembar observasi aktivitas mahasiswa.

\section{b. Pelaksanaan}

Pada siklus II membahas mengenai masalah Primal-Dual dalam Program Linier. Dosen membuka pelajaran dengan mengingatkan kembali langkah-langkah menyelesaikan masalah Program Linier dengan metode Simpleks. Selanjutnya, dosen menjelaskan hubungan timbal balik dengan permasalahan dalam Program Linier yang merupakan latarbelakan munculnya masalah Primal-Dual dalam Program Linier. Dengan bantuan slide presentasi yang telah disusun, dosen menjelaskan Teori Dualitas dalam Program Linier yang disertai dengan contoh-contoh yang relevan berdasarkan masalah Primal-Dual.

Selanjutnya, dosen membagi mahasiswa kedalam kelompok-kelompok kecil yang terdiri dari dua sampai tiga mahasiswa. Setiap kelompok diberikan satu soal permasalahan program linier yang akan diselesaikan dengan metode simpleks dan juga akan diselesaikan dengan LINDO 6.1. Pada tahap ini mahasiswa melakukan aksi (actions), proses (prosesses), dan objek (objects), serta skema (schema) terhadap petunjuk-petunjuk yang diberikan dosen mengenai langkah-langkah dalam menyelesaikan masalah Primal-Dual. Dalam tiap kelompok diskusi mahasiswa akan diberikan masalah Primal, kemudian membentuk Dual dari masalah Primal dengan syarat-syarat yang telah disajikan dosen dan menyelesaiakan masalah Primal atau Dual dengan metode Simpleks.

Kemudian mahasiswa mempresentasikan hasil diskusi berupa jawaban-jawaban atas pertanyaan seputar masalah Primal-Dual dan kelompok yang lain memberi tanggapan berupa masukan maupun pertanyaan jika terdapat bagian pembuktian yang tidak dipahami. Dosen memberikan penguatan dan penegasan jawaban diakhir diskusi dan bersama menarik kesimpulan apa yang telah dipelajari.

\section{c. Hasil Observasi}

Tabel 2. Hasil observasi aktivitas belajar mahasiswa siklus II

Rata-Rata skor

No. Indikator

Pert. $1 \quad$ Pert. 2

\begin{tabular}{|c|c|c|c|}
\hline 1. & $\begin{array}{l}\text { Kegiatan visual (visual } \\
\text { activities) }\end{array}$ & 2,0 & 3,0 \\
\hline 2. & $\begin{array}{l}\text { Kegiatan lisan } \quad \text { (oral } \\
\text { activities) }\end{array}$ & 1,0 & 2,0 \\
\hline 3. & $\begin{array}{l}\text { Kegiatan mendengarkan } \\
\text { (listening activities) }\end{array}$ & 2,0 & 3,0 \\
\hline 4. & $\begin{array}{l}\text { Kegiatan menulis (writing } \\
\text { activities) }\end{array}$ & 2,0 & 2,0 \\
\hline 5. & $\begin{array}{l}\text { Kegiatan motorik (motor } \\
\text { activities) }\end{array}$ & 2,0 & 2,0 \\
\hline 6. & $\begin{array}{l}\text { Kegiatan mental (mental } \\
\text { activities) }\end{array}$ & 2,0 & 3,0 \\
\hline \multicolumn{2}{|c|}{ Jumlah skor pertemuan } & 11,0 & 15,0 \\
\hline \multicolumn{2}{|c|}{$\begin{array}{l}\text { Rata-rata skor } \\
\text { Kategori aktivitas }\end{array}$} & \multicolumn{2}{|c|}{$\begin{array}{l}13,0 \\
\text { Aktif }\end{array}$} \\
\hline
\end{tabular}

d. Hasil Evaluasi

Evaluasi dilakukan pada 20 Jui 2016 dengan jumlah mahasiswa yang mengikuti tes adalah 19 orang dengan nilai tertinggi adalah 100 sedangkan 
nilai terendah adalah 50,0. Rata-rata kelas diperoleh sebesar 75,83 dimana sebanyak $52,63 \%$ mahasiswa memperoleh nilai dibawah 75 .

\section{e. Refleksi}

Proses pembelajaran mata kuliah Program Linier pada siklus II difokuskan agar mahasiswa dapat membentuk masalah Primal-Dual dan menyelesaikannya dengan metode Simpleks. Dari hasil pengamatan, dosen sudah menerapkan pembelajaran sesuai dengan langkah-langkah Teori APOS. Dari hasil yang dicapai pada siklus II terjadi peningkatan aktivitas dan hasil belajar dan sudah mencapai indikator keberhasilan yang diharapkan. Karena semua siklus telah dilaksanakan maka penelitian dihentikan di siklus II.

\section{f. Ringkasan Hasil Penelitian}

Ringkasan hasil penelitian dari Siklus I dan II disajikan dalam tabel berikut:

Tabel 3. Ringkasan hasil penelitian dari Siklus I dan II

\begin{tabular}{|c|c|c|c|}
\hline \multirow[t]{2}{*}{ Siklus } & \multicolumn{2}{|c|}{$\begin{array}{c}\text { Aktivitas Belajar } \\
\text { Mahasiswa }\end{array}$} & \multirow[t]{2}{*}{$\begin{array}{l}\text { Rata-Rata nilai } \\
\text { hasil belajar }\end{array}$} \\
\hline & Skor & Kategori & \\
\hline I & 9 & $\begin{array}{l}\text { Kurang } \\
\text { Aktif }\end{array}$ & 66,11 \\
\hline II & 13 & Aktif & 75,83 \\
\hline
\end{tabular}

\section{B. Pembahasan}

Indikator ketercapaian dalam penelitian ini adalah peningkatan aktivitas dan hasil belajar berupa pemahaman mahasiswa dalam memecahkan masalah Program Linier. Aktivitas belajar mahasiswa dikatakan meningkat jika terjadi peningkatan rata-rata skor aktivitas untuk setiap siklusnya dan minimal berkategori aktif. Sedangkan untuk pemahaman mahasiswa dalam memecahkan masalah Program Linier ditetapkan lebih besar atau sama dengan 75 .

Dari pelaksanaan pra tindakan diperoleh beberapa penyebab rendahnya hasil belajar Program Linier yang disebabkan oleh tiga faktor, yaitu mahasiswa, dosen, dan karakteristik Program Linier itu sendiri. Teori APOS dipilih sebagai solusi dari ketiga faktor tersebut. Kegiatan-kegiatan mental dalam Teori APOS yaitu aksi, proses, objek, dan skema, dapat membantu mahasiswa dengan kemampuan matematika yang rendah untuk dapat memahami konsep Program Linier. Pada tahap aksi, proses, objek, dan skema mahasiswa bereaksi terhadap petunjuk-petunjuk dalam penyelesaian masalah Program Linier yang memberikan rincian yang tepat mengenai tindakan yang tepat mengenai langkah-langkah apa yang harus diambil dalam menyelesaikan masalah Program Linier termasuk menghubungkan konsep-konsep sebelumnya yang berkaitan dengan Program Linier, dalam hal ini konsep eliminasi Gauss-Jordan.

Pada siklus I dan II menunjukkan peningkatan hasil belajar dan aktivitas baik dalam kegiatan visual, lisan, mendengarkan, menulis, motoric, dan kegiatan mental baik dalam proses pembelajaran, proses diskusi, hingga mempresentasikan hasil kerja kelompoknya. Pada siklus I, rata-rata skor aktivitas sebesar 9,0 dengan kategori kurang aktif. Mahasiswa masih kurang dalam kegiatan lisan berupa mengajukan pertanyaan dan mengemukakan pendapat. Begitu juga kegiatan mental dalam memecahkan masalah dalam LKM, menganalisis, dan melihat hubungan-hubungan dalam tiap variabel dalam masalah Program Linier. Pada siklus II terjadi peningkatan aktivitas dimana rata-rata skor 13,00 dengan kategori aktif. Mahasiswa sudah mampu dan tidak malu-malu dalam mengajukan pertanyaan baik dalam proses pembelajaran ataupun proses diskusi. Mahasiswa juga sudah berani mengajukan pendapat dalam proses diskusi dan mahasiswa juga sudah mampu menganalisis dan menghubungkan tiap-tiap variabel dalam permasalahan yang ditandai dengan hasil diskusi semua kelompok yang sudah menjawab dengan benar baik dari LKM ataupun dengan menggunakan software LINDO 6.1.

Sedangkan hasil belajar pada siklus I diperoleh rata-rata kelas sebesar 66,11 dimana sebanyak $57 \%$ mahasiswa memperoleh nilai dibawah 75. Dari hasil evaluasi siklus I, mahasiswa masih kurang dalam hal mengisi datadata pada tabel tiap iterasi, pemilihan elemen kunci, kesalahan perhitungan aljabar tiap iterasi. Dosen melakukan perbaikan dalam hal kekurangan-kekurangan dalam siklus I, salah satunya menegaskan kembali proses pencarian solusi dengan metode simpleks baik dalam hal input data, pemilihan elemen kunci, dan memberikan saran-saran agar perhitungan aljabar tiap iterasi tidak mengalami kesalahan. Pada siklus II terjadi peningkatan hasil belajar dengan rata-rata kelas sebesar 75,83 dimana sebanyak $52,63 \%$ mahasiswa memperoleh nilai diatas 75 dan sudah mencapai indikator keberhasilan yang ditetapkan.

Penerapan model Teori APOS pada pembelajaran Program Linier cukup dapat memberikan peningkatan aktivitas dan hasil belajar mahasiswa. Secara individu, mahasiswa mulai belajar mengkomunikasikan ide atau pendapatnya dalam menyelesaiakn masalahmasalah Program Liner dengan mengkonstruksi pemahaman melalui konstruksi-konstruksi aksi (action), proses (prosesses), objek (objects), dan skema (schema). Ini ter tercermin dari sajian hasil diskusi kelompok, interaksi antar kelompok komunitas kelas yang multi arah, penggunaan 
siklus ACE (aktivitas diskusi kelas, pengerjaan dengan computer, dan latihan). Penggunaan siklus ACE dimaksudkan agar mahasiswa terbantu dalam melakukan konstruksi-konstruksi mental yang diperlukan untuk memahami ide-ide dalam konsep Program Linier. Ini semua dapat diduga sebagai faktor penyebab keunggulan teori APOS terhadap pembelajaran secara konvensional atau biasa dalam mengembangkan kemampuan dalam menyelesaikan masalahmasalah dalam Program Linier.

\section{KESIMPULAN}

Penerapan Teori APOS sudah dapat meningkatkan kemampuan mahasiswa dalam memecahkan masalah dalam Program Linier dimana pada siklus I, rata-rata skor aktivitas sebesar 9,0 dengan kategori kurang aktif dan meningkat pada siklus II sebesar 13,0 dengan kategori aktif. Sedangkan hasil belajar pada siklus I diperoleh rata-rata kelas sebesar 66,11 dimana sebanyak 57,89\% mahasiswa memperoleh nilai dibawah 75. Pada siklus II terjadi peningkatan hasil belajar dengan rata-rata kelas sebesar 75,83 dimana sebanyak 52,63\% mahasiswa memperoleh nilai dibawah 75 dimana nilai ini sudah mencapai indikator keberhasilan yang ditetapkan.

\section{DAFTAR PUSTAKA}

Arnawa, IM. et al. 2007. "Applying The APOS Theory to Improve Student Ability to Prove in Elementary Abstract Algebra". Journal of The Indonesian Mathematical Society. 13(1), 133-148.

Arnawa, Made. 2009. Mengembangkan Kemampuan Mahasiswa dalam Memvalidasi Bukti pada Aljabar Abstrak melalui Pembelajaran Berdasarkan Teori APOS. Jurnal Matematika dan Sains Juni 2009. Vol. 14 No. 2.

Dubinsky, E. and M. McDonald. 2001. APOS: A Constructivist Theory of Learning. Kluwer Academic Publishers, Dordrecht, 275-282. 